Historic, Archive Document

Do not assume content reflects current scientific knowledge, policies, or practices. 

SPECIAL BULB LISTEFOR 1902 August to November Delivery $P Y$,

\section{HIGHLANDS NURSERY}

In the Carolina Mountains

\section{TRADE PRICES OF}

\section{Hardy Native American Bulbs and Plants}

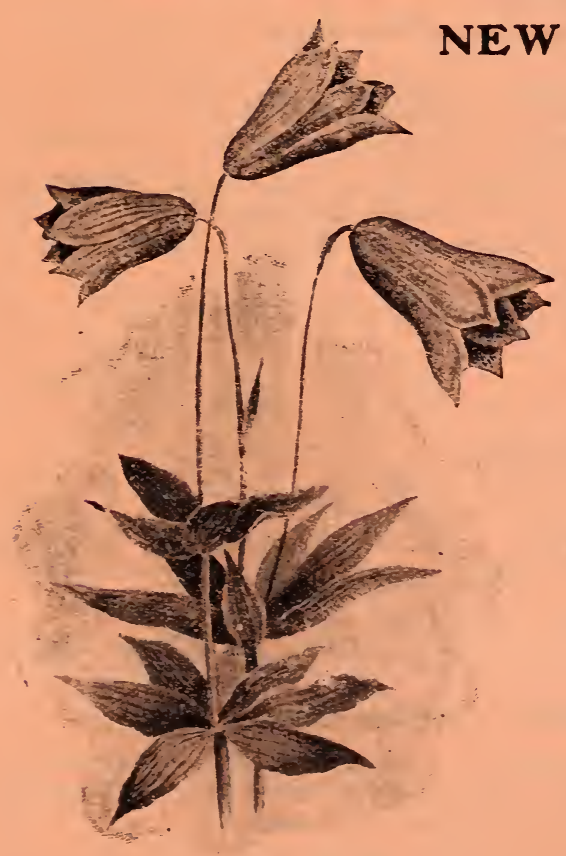

LILIUM GRAYI

Introduced by Harlan P. Kelsey

-

\section{NOTE SPECIAL OFFERS OF}

Cypripedium reginæ (spectabile) and hirsutum

Lilium superbum and grayi,

Trillium grandiflorum, Sanguinaria canadensis, Shortia galacifolia, Dionæa muscipula, and the grand $\mathrm{New}$

Improved Pink Water Lily Castalia (Nymphæa) Brakeleyi rosea

\section{HARLAN P. KELSEY, Exporter}

PROPRIETOR HIGHLANDS NURSERY KAWANA, N. C.

3,800 feet elevation where shipments are made
Tremont Building

BOSTON, MASS., U. S. A.

N. B.-Always address correspondence to Boston office and save delay. 


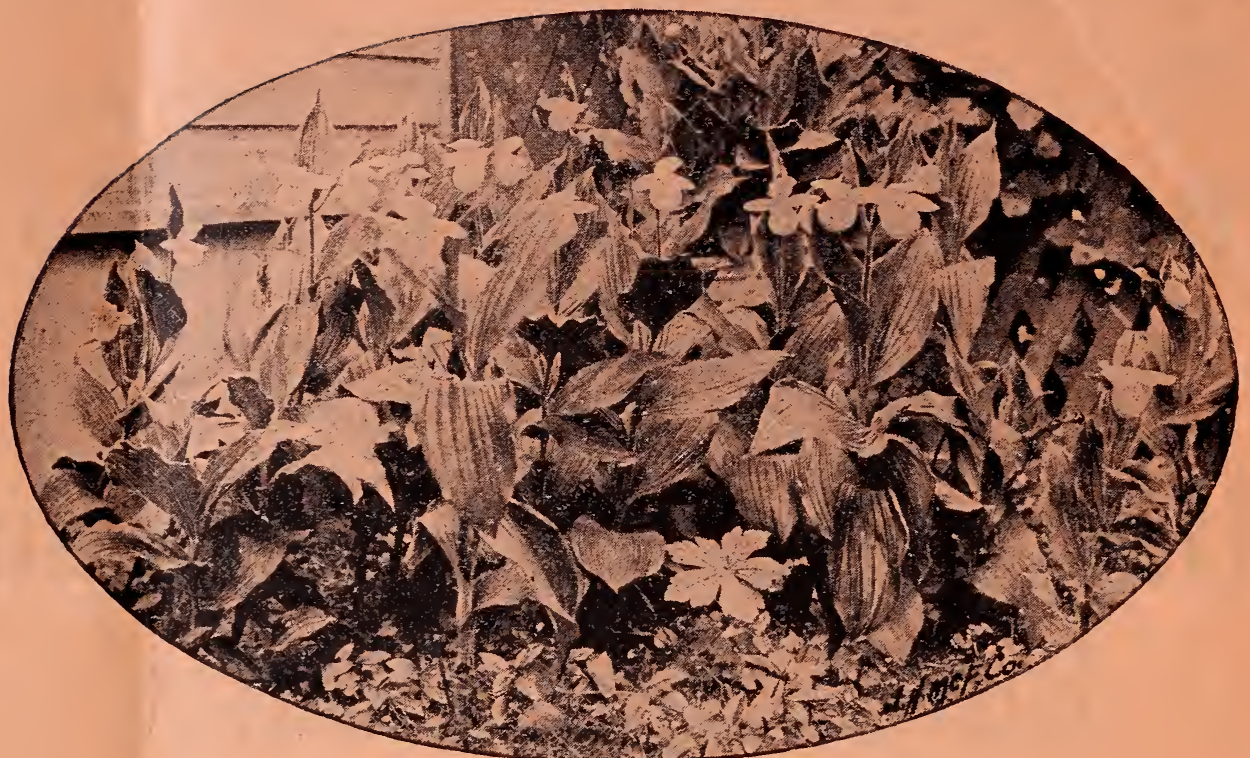

Cypripedium reginæ (spectabile), Showy Lady-Slipper

\section{CYPRIPEDIUM REGINAE (SPECTABILE) \\ (White and Pink Lady-Slipper.) Soo Illustration}

We offer an exceptional stock of this, the finest of all American Terrestrial Orchids, at low rates for advance orders. Our foreign correspondents will be particularly pleased to be able to secure at a low rate a stock of this rare and beautiful orchid.

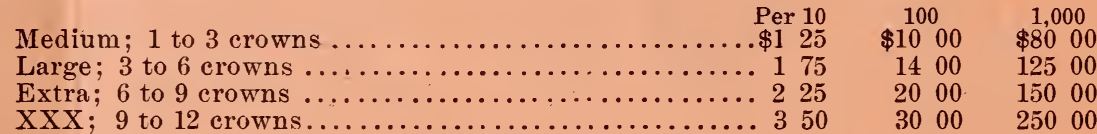

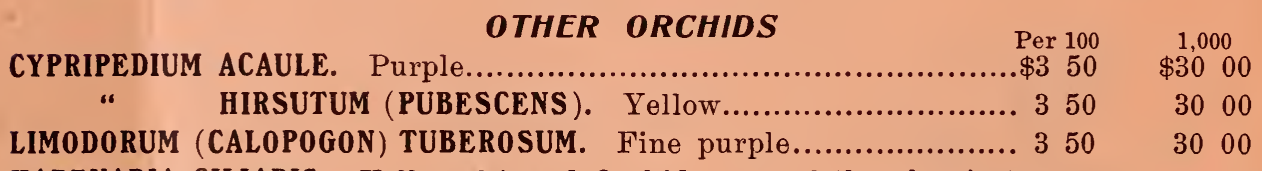

HABENARIA CILIARIS. Yellow-fringed Orchid; one of the showiest

of all, thriving in all kinds of soil............................................ $350 \quad 3000$

\section{LILIUM SUPERBUM (Turk's-Cap Lily)}

No description will do justice to this magnificent American Lily. A clump of them is literally a "blaze of scarlet and gold." For years we have made the growing of this Lily a specialty, and send out thousands of bulbs every season.

Our stock this season is very fine, and we are offering at a low price, for the benefit of large planters and those wishing to catalogue it. Of special use for planting in Rhododendron beds. Note low prices:

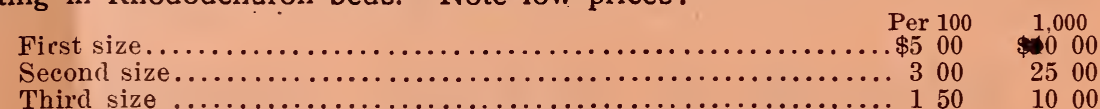

\section{LILIUM GRAYI (Gray's Lily)}

Introduced by Harlan P. Kelsey. See lllustration

Since introducing this beautiful and rare Lily in 1888 , many thousands have been sent out to all parts of the world, and it is considered one of the best, most distinct and showy of the family.

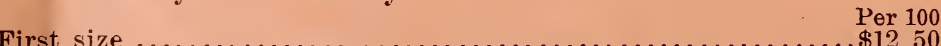

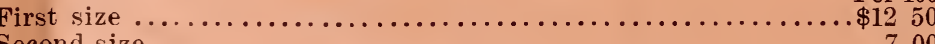




\section{LILIUM CAROLINIANUM}

A new and rare species and a raluable addition to our native Lilies. Flowers much like L. superbum but the plant is of lower growth.

\section{TRILLIUMS (Wood Lilies)}

The Trilliums, especially $T$. grandiflorum, are of special value for massing in plantation borders and under trees. They are cheap and give quick effect. Ready in August.

\begin{tabular}{|c|c|c|c|c|}
\hline Trillium & grandiflorum & $\begin{array}{c}\text { Per } 1 \\
\ldots \$ 8\end{array}$ & & $\begin{array}{c}5.000 \\
\$ 3500\end{array}$ \\
\hline & er & $\ldots . .12$ & & \\
\hline & & $\ldots 12$ & & 50 \\
\hline
\end{tabular}

\section{RARE BULBS AND PLANTS}

CASTALIA (NYMPHAEA) odorata (White Fragrant Water Lily). Few aquatics equal this for hardiness and effect. Any quantity of strong roots can be supplied

" “ $\quad$ rosea. The famous Cape Cod Pink Pond

Lily. We export large quantities

every year....................\$5 for $10 \ldots 4500$

CIMICIFUGA racemosa and americana. The Cimicifugas are particularly adapted to woods planting, where they thrive and produce very showy spikes and trusses of white flowers. Clumps..2,000 at $\$ 20$ per $1,000 \ldots 300$

DIONAEA muscipula (Tenus' Fly Trap). We have been headquarters for this rare and curious insectivorous plant for many years. Can be mailed or expressed at any time of the year. Strong plants..... 400

PORTERANTHUS (GILLENIA) stipulatus. In masses this feathery plant produces a most beautiful effect, and is exceedingly floriferous. Cut foliage and white, paper-like flowers with bright pink stamens. Strong clumps............................................................... 400

GENTIANA andrewsii (Closed Gentian). An unlimited supply of this popular late-blooming plant. Strong roots

HELONIAS bullata. An exceedingly rare and showy bog plant, the large purple flowers appearing in March and April. $\$ 3$ per 100, $\$ 20$ per 1,000 .

IRIS cristata and verna. Strong nurserygrown clumps. $\$ 5$ per 100 .

IRIS cristata and verna. Collected. $\$ 2$ per $100, \$ 12$ per 1,000 .

NYMPHAEA (NUPHAR) sagittifolia. Tery rare. $\$ 4$ for $10, \$ 30$ per 100 .

SANGUINARIA canadensis (Blood Root). All large orders should be placed at once. We cannot supply in quantity after August. Strong roots. $\$ 2$ per $100, \$ 8$ per 1,000 .

SARRACENIAS. We make a specialty in supplying the rare species, and invite correspondence.

SHORTIA galacifolia. The beautiful and rare Shortia introduced by us. A fine stock of strong, established plants on hand. Strong. $\$ 5$ per $100, \$ 35$ per 1,000 .

Hearier clumps. $\$ 10$ per 100 .

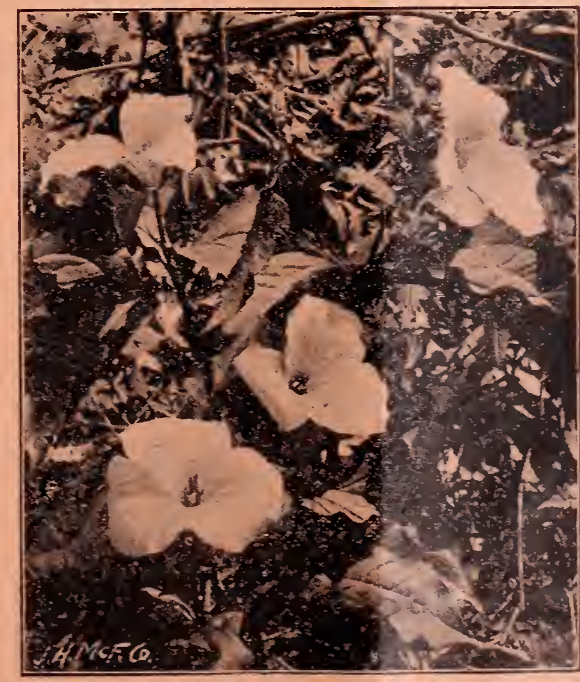

Trillium grandiflorum. 


\section{OTHER HERBACEOUS PERRENNIALS}

ACONITUM uncinatum. Fine Per 10 Per 100 Per 1,000 BAPTISIA tinctoria. $\$ 075 \quad \$ 400 \quad \$ 3000$ EUPHORBIA corollata. $75 \quad 300$

. $50 \quad 300$

MONARDA didyma coccinea. Strong................................ $100 \quad 700$

\section{CASTALIA (NYMPHAEA) BRAKELEYI ROSEA}

Improvod PInk Water Lily

A new magnificent hybrid from the best form of Castalia tuberosa erossed with the rare Cape Cod Pink Water Lily. The original plant produces leaves 16 inches in diameter and flowers 8 inches across, of a beautiful pink, the richest and most powerful fragrance of the hardy varieties. $\$ 2$ each, $\$ 16$ for 10 . Special prices per 100 .

\section{NATIVE FERNS}

A fine collection of hardy native Ferns suitable for park and cemetery planting, including the following varieties:

Adiantum pedatum,
Dryopteris acrostichoides,
Dryopteris marginalis,

Dryopteris spinulosa,

Dicksonia punctilobula,

Onoclea sensibilis,
Osmunda, in 3 vars.,

Polypodium vulgare,

Pteris aquilina, and others.

Strong, nursery-grown elumps at $\$ 4$ per $100, \$ 35$ per 1,000 ; collected at $\$ 10$ to $\$ 15$ per 1,000 .

\section{AMPELOPSIS ENGELMANNI}

This is the clinging form of the well-known Virginia Creeper, and was introduced by us several seasons ago. The leaves are much thinner and smaller than in the ordinary variety, and the whole plant lacks the coarseness that characterizes the $A$. quinquefolia, and it clings to walls like the ivv. The fall coloring is exceedingly brilliant. A fine stock ready for fall delivery.

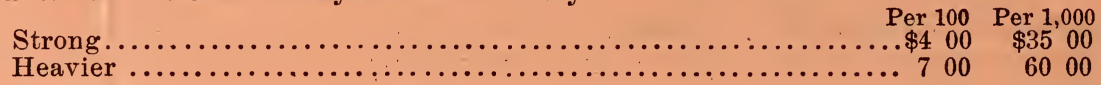

\section{GINSENG (Aralia quinquefolia)}

A revised edition of my illustrated pamphlet on the subject of Ginseng culture will be mailed on receipt of 10 cents. This is the best work published, and gives full instructions, enabling anyone to grow this extremely valuable root. Price-list of seeds and plants free.

ALL THE BULBS AND PLANTS listed above can be expressed during August and September, or can be held and shipped with freight orders for trees and shrubs in October and November, but orders should be placed now to insure stock being reserved.

\section{HARDY AMERICAN SHRUBS AND TREES}

Our stock of fine and rare plants for fall delivery is larger than ever, and the damp season being exceptionally favorable, it has made an extra strong, vigorous growth. A splendid variety of Azaleas, Andromedas, Hemlocks, Leiophyllums, etc. Write for special advance prices.

RHODODENDRONS, KALMIAS, LEUCOTHOËS, GALAX and other fine shrubs and plants for use in massing effects, we collect by the car-load in fine clumps for immediate effect with perfect success. Special prices made and correspondence solicited.

We publish a unique catalogue, dealing entirely with Native Plants and filled with original illustrations, and send it to any address. Also a wholesale catalogue for the trade only.

Always address Boston office,

\section{HARLAN P. KELSEY}

